\title{
THE INCIDENCE AND DEMONSTRATION OF BIOLOGIC REACTIONS IN ROUTINE WASSERMANN TESTS*
}

\author{
BY \\ H. M. RICE \\ From the Department of Pathology, General Hospital, Nottingham
}

For the past 30 years the M.R.C. No. 1, with its later development the Harrison-Wyler method, has been the premier Wassermann technique in Great Britain. It is probably still the most commonly used, though now being superseded by methods based on optimal proportions which are both more sensitive and more specific. The object of this paper is to show that, by means of a simple modification, the Harrison-Wyler technique can be made to distinguish a large percentage of non-syphilitic, or biologic, from syphilitic positive reactions. The modification also increases the sensitivity of the test (Rice, 1950).

The American term "biologic", though not altogether satisfactory, is chosen instead of some English phrase such as non-specific, because the whole Wassermann procedure is non-specific in the immunological sense, and the term "false positive" is becoming restricted to causation by technical faults or bacterial contamination. Furthermore, the major part of the very large literature on this subject is American.

\section{Principles and Method}

The dilute-antigen technique, first described by Sordelli (1931) as a method of increasing the sensitivity of Wassermann procedures, was brought to notice in Great Britain by Richardson (1940). The principle is that a smaller quantity of antigen will often react sufficiently with a weak serum to fix complement, when the full amount of antigen is unable to do so, not being in the optimal ratio. Since complement fixation is maximal in the zone of moderate antibody excess, a strong serum will remain positive. If, on the other hand, the reaction is due to some non-syphilitic antibody, or to unknown haptens in the antigen extract, dilution of the antigen suspension will demonstrably reduce their ability to cause fixation. In practice, this theoretical basis is amply borne out. Weak sera show less and most biologic sera show more haemolysis with the dilute antigen than with the full strength suspension.

In 1945, J. W. Lacey, after reading Richardson's paper, introduced the simple modification of adding a dilute-antigen row to the standard Harrison-Wyler technique, using in it 1/90 antigen suspension and 3

\footnotetext{
* Received for publication July 29, 1952.
}

M.H.D. of complement. This method, the HarrisonWyler-Lacey or H.W.L. technique, was adopted as standard by the British Army in 1948. The writer has been unable to find any reference to any comparable dilute-antigen technique so far in the American literature.

Apart from general theoretical interest, particular attention was focused on the problem of the biologic Wassermann reaction by the change from military to civil experience. It soon became evident that civilian biologic reactions are commoner than the 0.79 per cent. encountered in a published Army series of nearly 15,000 results (Rice, 1950). As, however, general impressions are notoriously unreliable, a record has been kept of the readings of all tests over a period of $1 \frac{1}{2}$ years, to enable an analysis to be made of the incidence and significance of biologic reactions. All strengths of reactions are considered in this paper, and it must be stressed that the dilute-antigen techniques permit a more sensitive test than the standard, since specificity is also increased. Many minimal reactions are included which are, in fact, immediately disregarded when reporting the tests, but which are of significance in interpreting the value of the procedure.

This paper is based on a series of 15,835 consecutive routine Wassermann reactions, excluding repeat tests, over a period of nearly 16 months. Technical false positives could not be excluded in a few instances, as when specimens were insufficient to allow repeat tests, or during the writer's absence. This may partly explain the high figures for the series.

\section{Results}

The results are summarized in Table $I$. For comparison with other series, in most of which the very weak reactions are ignored, the totals excluding minimal reactions are also shown. By "minimal reaction " is meant 75 per cent. or more haemolysis

TABLE I

SUMMARY OF FRANK BIOLOGIC (F.B.) REACTIONS

\begin{tabular}{|c|c|c|c|c|c|c|c|}
\hline \multirow{3}{*}{ Reactions } & \multirow{3}{*}{$\begin{array}{l}\text { Total } \\
\text { Tests }\end{array}$} & \multicolumn{6}{|c|}{ F.B. Reactions } \\
\hline & & \multicolumn{2}{|c|}{+} & \multicolumn{2}{|c|}{ \pm} & \multicolumn{2}{|c|}{ Total } \\
\hline & & No. & $\begin{array}{l}\text { Per- } \\
\text { cent. }\end{array}$ & No. & $\begin{array}{l}\text { Per- } \\
\text { cent. }\end{array}$ & No. & $\begin{array}{l}\text { Per- } \\
\text { cent. }\end{array}$ \\
\hline All F.B. $\quad$. & \multirow{2}{*}{15,835} & 52 & 0.33 & 187 & $1 \cdot 18$ & 239 & $1 \cdot 51$ \\
\hline Minimals excluded & & 52 & $0 \cdot 33$ & 89 & 0.56 & 141 & 0.89 \\
\hline
\end{tabular}


in one of the 3 M.H.D. rows, the other two rows being clear. If this occurs in the tube with $1 / 15$ antigen the reaction is frankly biologic, and is referred to in this paper as a Frank Biologic or F.B. reaction. In all instances, "positive" $(+)$ and "doubtful" $( \pm)$ are used according to their interpretation in the Harrison-Wyler method.

The sera were from patients in both V.D. clinics and hospitals, and subdivision by these categories, and also by sex incidence, shows marked differences (Tables II, III, and IV).

\section{TABLE II}

SEX INCIDENCE OF F.B. REACTIONS

\begin{tabular}{l|c|r|r|r|r|r|r}
\hline \multirow{2}{*}{ Sex } & \multirow{2}{*}{$\begin{array}{l}\text { Total } \\
\text { Tests }\end{array}$} & \multicolumn{2}{|c|}{ F.B. } & \multicolumn{2}{|c|}{+} & \multicolumn{2}{|c}{ \pm} \\
\cline { 3 - 8 } & No. & $\begin{array}{l}\text { Per- } \\
\text { cent. }\end{array}$ & No. & $\begin{array}{r}\text { Per- } \\
\text { cent. }\end{array}$ & No. & $\begin{array}{l}\text { Per- } \\
\text { cent. }\end{array}$ \\
\hline F & 7,461 & 148 & 1.98 & 35 & $0 \cdot 47$ & 113 & $1 \cdot 51$ \\
\hline M & 8,374 & 91 & 1.09 & 17 & $0 \cdot 20$ & 74 & 0.88 \\
\hline
\end{tabular}

TABLE III

TOTAL INCIDENCE OF F.B. REACTIONS IN V.D. CLINICS

\begin{tabular}{|c|c|c|c|c|c|c|}
\hline \multirow{3}{*}{ Sex } & \multicolumn{3}{|c|}{ V.D. Clinics } & \multicolumn{3}{|c|}{ Hospitals } \\
\hline & \multirow{2}{*}{$\begin{array}{l}\text { Total } \\
\text { Tests }\end{array}$} & \multicolumn{2}{|c|}{ F.B. Reactions } & \multirow{2}{*}{$\begin{array}{l}\text { Total } \\
\text { Tests }\end{array}$} & \multicolumn{2}{|c|}{ F.B. Reactions } \\
\hline & & No. & Percent. & & No. & Percent. \\
\hline $\begin{array}{l}\mathrm{F} \\
\mathbf{M}\end{array}$ & $\begin{array}{l}2,239 \\
3,980\end{array}$ & $\begin{array}{l}79 \\
52\end{array}$ & $\begin{array}{l}3.53 \\
1.31\end{array}$ & $\begin{array}{l}5,222 \\
4,394\end{array}$ & $\begin{array}{l}69 \\
39\end{array}$ & $\begin{array}{l}1.32 \\
0.89\end{array}$ \\
\hline
\end{tabular}

TABLE IV

FULL ANALYSIS OF F.B. REACTIONS

\begin{tabular}{|c|c|c|c|c|c|c|c|c|c|c|}
\hline \multirow{3}{*}{ Sex } & \multirow{3}{*}{ Place } & \multirow{3}{*}{$\begin{array}{l}\text { Total } \\
\text { Tests }\end{array}$} & \multicolumn{8}{|c|}{ F.B. } \\
\hline & & & \multicolumn{2}{|c|}{+} & \multicolumn{2}{|c|}{ \pm} & \multicolumn{2}{|c|}{$\begin{array}{l}\text { Mini- } \\
\text { mals }\end{array}$} & \multicolumn{2}{|c|}{ Total } \\
\hline & & & No. & $\begin{array}{l}\text { Per- } \\
\text { cent. }\end{array}$ & No. & $\begin{array}{l}\text { Per- } \\
\text { cent. }\end{array}$ & No. & $\begin{array}{l}\text { Per- } \\
\text { cent. }\end{array}$ & No. & $\begin{array}{l}\text { Per- } \\
\text { cent. }\end{array}$ \\
\hline \multirow{2}{*}{$\mathbf{F}$} & V.D.Clinics & 2,239 & 25 & $1 \cdot 12$ & 27 & $1 \cdot 20$ & 27 & $1 \cdot 20$ & 79 & 3.53 \\
\hline & Hospital & 5,222 & 10 & $0 \cdot 19$ & 23 & 0.44 & 36 & 0.69 & 69 & $1 \cdot 32$ \\
\hline \multirow{2}{*}{$\mathbf{M}$} & V.D.Clinics & 3,980 & 10 & 0.25 & 23 & 0.58 & 19 & 0.48 & 52 & $1 \cdot 31$ \\
\hline & Hospital & 4,394 & 7 & 0.16 & 16 & $0 \cdot 36$ & 16 & $0 \cdot 36$ & 39 & 0.89 \\
\hline
\end{tabular}
AND HOSPITALS

These figures apply to Frank Biologic reactions recognizable on sight, and this type forms a high proportion of all biologic reactions. The actual percentage is important for proving the increased specificity of the H.W.L. technique. Table V shows the totals of Frank Biologic reactions correlated with the total of all biologic reactions. The latter figure was obtained by analysing the final diagnoses of all cases showing a positive or doubtful reaction. All cases finally diagnosed as syphilis were then excluded, although it is well recognized that some positive results in sero-positive syphilitics may be biologic in nature. For the remaining nonsyphilitic positive and doubtful reactions of syphilitic type the term "masked biologic" is used in this paper. Such reactions can only be distinguished as biologic on final review of the cases concerned.

TABLE V

SUMMARY OF ALL BIOLOGIC RESULTS

\begin{tabular}{|c|c|c|c|c|c|c|c|}
\hline \multirow{2}{*}{\multicolumn{2}{|c|}{ Results }} & \multicolumn{2}{|c|}{ Total } & \multicolumn{2}{|c|}{+} & \multicolumn{2}{|c|}{ \pm} \\
\hline & & No. & $\begin{array}{c}\text { Per- } \\
\text { cent.* }\end{array}$ & No. & $\begin{array}{l}\text { Per- } \\
\text { cent. }\end{array}$ & No. & $\begin{array}{l}\text { Per- } \\
\text { cent. }\end{array}$ \\
\hline Frank Biologic. . & . & 239 & $1 \cdot 51$ & 52 & $0 \cdot 33$ & 187 & $1 \cdot 18$ \\
\hline Masked Biologic & .. & 51 & 0.32 & 16 & $0 \cdot 10$ & 35 & $0 \cdot 22$ \\
\hline Total & .. & 290 & $1 \cdot 83$ & 68 & 0.43 & 222 & $1 \cdot 40$ \\
\hline Excluding Minimals & . & 189 & $1 \cdot 19$ & 68 & 0.43 & 96 & 0.61 \\
\hline
\end{tabular}

* Percentages refer to total tests $(15,835)$.

Certain of the doubtful reactions are only detectable by the dilute-antigen tube, and would be called negative in the standard Harrison-Wyler test. These are shown in the column H.W.L., in the final analysis (Table VI).

The most important aspect of these figures is the percentage of the total biologics labelled "Frank Biologics" and immediately diagnosed as such (Table VII). No definite instance of wrongly labelled F.B. reactions has been detected in this series, although six female and five male known

TABLE VI

FULL ANALYSIS OF ALL BIOLOGIC REACTIONS

\begin{tabular}{|c|c|c|c|c|c|c|c|c|c|c|c|c|c|c|c|c|c|c|c|c|}
\hline \multirow{3}{*}{ Sex } & \multirow{3}{*}{ Place } & \multirow{3}{*}{$\begin{array}{l}\text { Total } \\
\text { Cases }\end{array}$} & \multicolumn{10}{|c|}{ Biologic Reactions } & \multicolumn{8}{|c|}{ Excluding Minimal Reactions } \\
\hline & & & \multicolumn{2}{|c|}{+} & \multicolumn{2}{|c|}{ \pm} & \multicolumn{2}{|c|}{ MinimalF.B. } & \multicolumn{2}{|c|}{ H.W.L. } & \multicolumn{2}{|c|}{ Total } & \multicolumn{2}{|c|}{+} & \multicolumn{2}{|c|}{ \pm} & \multicolumn{2}{|c|}{ H.W.L. } & \multicolumn{2}{|c|}{ Total } \\
\hline & & & No. & $\begin{array}{c}\text { Per- } \\
\text { cent.* }\end{array}$ & No. & $\begin{array}{l}\text { Per- } \\
\text { cent. }\end{array}$ & No. & $\begin{array}{l}\text { Per- } \\
\text { cent. }\end{array}$ & No. & $\begin{array}{l}\text { Per- } \\
\text { cent. }\end{array}$ & No. & $\begin{array}{l}\text { Per- } \\
\text { cent. }\end{array}$ & No. & $\begin{array}{l}\text { Per- } \\
\text { cent. }\end{array}$ & No. & $\begin{array}{l}\text { Per- } \\
\text { cent. }\end{array}$ & No. & $\begin{array}{l}\text { Per- } \\
\text { cent. }\end{array}$ & No. & $\begin{array}{l}\text { Per- } \\
\text { cent. }\end{array}$ \\
\hline & V.D. & 2,239 & 25 & $1 \cdot 12$ & 30 & $1 \cdot 34$ & 27 & $1 \cdot 20$ & 0 & - & 82 & $3 \cdot 66$ & 25 & $1 \cdot 12$ & 30 & $1 \cdot 34$ & 0 & - & 55 & $2 \cdot 46$ \\
\hline & Hospital & 5,222 & 15 & $0 \cdot 29$ & 34 & 0.65 & 36 & 0.69 & 2 & 0.04 & 87 & 1.66 & 15 & $0 \cdot 29$ & 34 & 0.65 & 1 & 0.02 & 49 & 0.94 \\
\hline \multirow{2}{*}{$\mathbf{M}$} & V.D. & 3,980 & 19 & 0.48 & 30 & $0 \cdot 75$ & 19 & 0.48 & 3 & 0.08 & 71 & 1.78 & 19 & 0.48 & 30 & 0.75 & 3 & 0.08 & 49 & 1.23 \\
\hline & Hospital & 4,394 & 9 & $0 \cdot 20$ & 22 & 0.50 & 16 & $0 \cdot 36$ & 3 & 0.07 & 50 & $1 \cdot 14$ & 9 & $0 \cdot 20$ & 22 & 0.50 & 1 & 0.02 & 31 & 0.71 \\
\hline
\end{tabular}

* Percentages refer to total number of cases. 
TABLE VII

F.B. REACTIONS AS PERCENTAGE OF ALL BIOLOGIC REACTIONS

\begin{tabular}{|c|c|c|c|c|c|c|c|c|c|c|}
\hline \multirow{3}{*}{ Sex } & \multirow{3}{*}{ Place } & \multicolumn{9}{|c|}{ Reactions } \\
\hline & & \multicolumn{3}{|c|}{+} & \multicolumn{3}{|c|}{ \pm} & \multicolumn{3}{|c|}{ Total } \\
\hline & & No. & Total & Percent. & No. & Total & Percent. & No. & Total & Percent. \\
\hline \multirow{3}{*}{$\mathbf{F}$} & V.D. Clinics & 25 & 25 & 100 & 54 & 57 & 95 & 79 & 82 & 96 \\
\hline & Hospital & 10 & 15 & 67 & 59 & 71 & 83 & 69 & 86 & 80 \\
\hline & Total & 35 & 40 & - & 113 & 128 & - & 148 & 168 & 88 \\
\hline \multirow{3}{*}{$\mathbf{M}$} & V.D. Clinics & 10 & 19 & 53 & 42 & 53 & 79 & 52 & 72 & 72 \\
\hline & Hospital & 7 & 9 & 78 & 32 & 41 & 78 & 39 & 50 & 78 \\
\hline & Total & 17 & 28 & - & 54 & 94 & - & 91 & 122 & 75 \\
\hline Total & $\ldots$ & $\ldots$ & . & $\ldots$ & .. & $\ldots$ & . & 239 & 290 & 82 \\
\hline
\end{tabular}

syphilitics did show repeated F.B. reactions, with subsequent typically positive sera. All sera showing F.B. reactions were retested on the same day. Table VII shows that 88 per cent. of biologic reactions in female cases, and 75 per cent. in males, were detected by the H.W.L. method.

Biologic Reactions in Pregnancy.-The findings in this series confirm the impression that pregnant women not infrequently show the F.B. type of reaction. The figures for 1,220 hospital cases are shown in Table VIII. The series included sera from 29 pregnancies forwarded from the V.D. clinics. Of these three showed biologic reactions, but the numbers are too small to be of significance.

TABLE VIII

F.B. REACTIONS IN PREGNANT HOSPITAL PATIENTS

\begin{tabular}{|c|c|c|c|c|c|c|c|c|c|}
\hline \multirow{2}{*}{\multicolumn{2}{|c|}{ Reactions }} & & \multirow{2}{*}{$\begin{array}{l}\text { Total } \\
\text { Cases }\end{array}$} & \multicolumn{2}{|c|}{+} & \multicolumn{2}{|r|}{+} & \multicolumn{2}{|c|}{ Total } \\
\hline & & & & No. & $\begin{array}{l}\text { Per- } \\
\text { cent. }\end{array}$ & No. & $\begin{array}{l}\text { Per- } \\
\text { cent. }\end{array}$ & No. & $\begin{array}{l}\text { Per- } \\
\text { cent }\end{array}$ \\
\hline Total Hospital & Cases & . & 5,222 & 10 & $0 \cdot 19$ & 59 & $1 \cdot 13$ & 69 & $1 \cdot 32$ \\
\hline Pregnant .. & .. & $\ldots$ & 1,220 & 5 & 0.41 & 25 & $2 \cdot 05$ & 30 & $2 \cdot 46$ \\
\hline Non-pregnant & $\ldots$ & .. & 4,002 & 5 & $0 \cdot 12$ & 34 & 0.85 & 39 & 0.97 \\
\hline
\end{tabular}

Other Conditions Causing Biologic Reactions.Analysis of the results in this series has yielded only negative evidence. The higher percentage of F.B. reactions in clinic than in hospital cases was unexpected, for the hospital patients included many suffering from febrile conditions known to cause occasional biologic positives. The highest figures for the series were found among the female V.D. patients. It was noted that the majority of those showing F.B. reactions, suffered from treated tertiary or congenital syphilis, but the impression of undue frequency was erroneous (Table IX). In both conditions, the F.B. reactions formed almost the same percentage of the total F.B.s as the conditions themselves did of the total female V.D. cases.

TABLE IX

INCIDENCE OF F.B. REACTIONS IN TREATED FEMALE V.D. CASES

\begin{tabular}{|c|c|c|c|}
\hline Total F.B. results in all Female V.D. cases .. & . & . & 33 \\
\hline 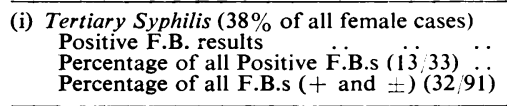 & $\begin{array}{l}\because \\
\cdots \\
\cdots\end{array}$ & $\begin{array}{l}\cdots \\
\cdots \\
\cdots\end{array}$ & $\begin{array}{l}13 \\
39 \\
35\end{array}$ \\
\hline $\begin{array}{l}\text { (ii) Congenital Syphilis }(12 \% \text { of all female cases) } \\
\text { Positive F.B. results } \\
\text { Percentage of all Positive F.B.s }(4 / 33) \\
\text { Percentage of all F.B.s }(+ \text { and } \pm)(14 / 91)\end{array}$ & $\begin{array}{l}\cdots \\
\cdots\end{array}$ & $\begin{array}{l}\cdots \\
\cdots\end{array}$ & $\begin{array}{r}4 \\
12 \\
15\end{array}$ \\
\hline
\end{tabular}

\section{Discussion}

The figures illustrate the value of modifying the Harrison-Wyler technique by the addition of a dilute-antigen row. Over 80 per cent. of all the biologic reactions in this series were detected by the H.W.L. method. The antigen-dilution employed is $1 / 90$, but further dilution may be used if preferred. Harrison (1918) stated that the antigen extract should give complete fixation at a dilution of $1 / 250$. A small number of tests, using various dilutions up to $1 / 250$, has shown no discrepancies. Recent techniques, such as that of Price (1950), employ antigen at the optimal dilution, often $1 / 400$, and reactions of the F.B. type do not then occur. Since the interpretation of his results remains the responsibility of the serologist it is represented that all using the Harrison-Wyler method should modify it with some dilute-antigen technique, to assist in distinguishing biologic from syphilitic positive reactions, as well as to increase the sensitivity of the test.

Apart from pregnancy, no common cause of biologic reactions has been disclosed. Pregnancy, 
while generally admitted in Great Britain to be a cause per se, is discounted in recent reports from the U.S.A. (Beerman, 1945 ; Davis, 1944 ; Neurath, 1948 ; Stokes and James, 1949). In the present series the incidence of biologic reactions was higher in female than in male cases, which partly explains the increase over the previous Army series, which was almost exclusively male. From data so far collected, menstruation has not been shown to cause an increased incidence : but the number of cases is too small to permit the drawing of definite conclusions. No explanation has yet been found for the greater incidence in patients from V.D. clinics compared with hospital patients. But since serological fluctuation between positive and negative is a recognized phenomenon in treated syphilis cases, it seems reasonable to suppose that a similar alternation between the true syphilitic and frank biologic reactions may occur in certain individuals. The use of antigen at its optimal titre obviates this difficulty, as the F.B. type of reaction does not occur. Since adopting Price's method, the writer has been most impressed with its superiority over the techniques previously employed.

\section{Summary}

A simple dilute-antigen modification of the standard Harrison-Wyler Wassermann technique is of great value in distinguishing non-syphilitic, or biologic, from syphilitic positive reactions. Both the sensitivity and the specificity of the test are increased. It is concluded that some dilute-antigen modification should be employed by all users of the Harrison-Wyler method.

In a series of 15,835 tests, a total of 290 such reactions occurred. Of these 239 ( 82 per cent.) were detected as biologic by this technique.

Considerable differences were seen between female and male, and between clinic and hospital cases.

The percentage of biologic reactions was higher in pregnant women than in non-pregnant hospital cases. No other common cause for these reactions was found.

The writer wishes to express his thanks to Dr. J. D. Wrigley and to Mr. T. O. Roach for technical assistance, and to his clinical colleagues for providing much information about their cases.

\section{REFERENCES}

Beerman, H. (1945). Amer. J. med. Sci., 209, 525; 210, 524. Davis, B. D. (1944). Medicine, Baltimore, 23, 359.

Harrison, L. W. (1918). Spec. Rep. Ser. med. Res. Coun., Lond., No. 14.

Lacey, J. W. (1945). Personal communication.

Neurath, H. (1948). Amer. J. Med., 5, 670.

Price, I. N. Orpwood (1950). British Journal of Venereal Diseases, $26,33$.

Rice, H. M. (1950). J. roy. Army med. Cps, 95, 146.

Richardson, G. M. (1940). British Journal of Venereal Diseases, $16,166$.

Sordelli, A. (1931). In " Report of the Laboratory Conference on the Sero-diagnosis of Syphilis, Uruguay, 1930 ". Annex 4, p. 123. League of Nations Health Organization, Geneva. Quoted by Richardson (1940).

Stokes, J. H., and James, G. W. (1949). Amer. J. Syph., 33, 114. 